\title{
Growth and Future Prospects of MSME in India
}

\author{
Priyadarshani Zanjurne
}

\author{
Assistant Profes sor, Modern Institute of Business Management, Shivajinagar, Pune
}

\begin{abstract}
In recent years, the significance of MSME has been recognized in the world's countries for its major contribution in various socio-economic objectives such as higher economic growth and employment, output, nurturing entrepreneurship and encouragement and support for exports. MSME play a vital role in the industrial development of any country. The MSME sector is a backbone of Indian economy for its contribution to growth of Indian economy. This sector is very much important for moves towards a faster and inclusive growth of country. The MSME sector can help for achieving the target of Nation Manufacturing Policy that manufacturing should contribute $25 \%$ in India's GDP by 2022. For that purpose, the government of India has taken a good initiative of "Make in India". This paper is to focus on performance of $M S M E \&$ growth and opportunities. It is concluded that this sector significantly contributes in employment, exports and manufacturing output.
\end{abstract}

Keywords- MSME, Make in India, GDP, growth, employment, opportunities.

\section{INTRODUCTION}

Micro, Small and Medium Enterprises (MSME) sector has emerged as a highly vibrant and dynamic sector of the Indian economy over the last five decades. (Murthy, 2016). The MSME also play a important role in the development of the economy with their effective, efficient, flexible and innovative entrepreneurial spirit. (Dey, 2014). The MSME sector contributes notably to the country's overall industrial production output, emp loyment and exports. It is recognized with generating the maximum employment growth as well as accounting for a major share of industrial production and exports. They have distinctive advantages due to their size and they required low investment. They have relatively high capital-labor ratio and they require a minimum gestation period. They try to capture and focus smaller markets; they make sure a more fair distribution of national income. They make possible an effective utilization of capital and skill resources and they motivate the growth of industrial entrepreneurship. The MSME sector in India is vast heterogeneous in terms of the size, variety of product and services and level of technology. This sector is large contributes to the socioeconomic development of the country. The MSME sector is an important pillar of Indian economy as it contributes greatly to growth of Indian economy with a vast network of around 30 million units, creating employment of about 70 million, manufacturing more than 6000 products, contributing about $45 \%$ to manufacturing output and about $40 \%$ of exports, directly and indirectly. This sector even assumes greater importance now as the country moves towards a faster and inclusive growth agenda. Moreover, it is the MSME sector which can help realize the target of proposed National Manufacturing Policy of raising the share of manufacturing sector in GDP from $16 \%$ at present to $25 \%$ by the end of 2022 . (PlanningCommission) ${ }^{1}$. The objective of paper is to find current status of performance of MSMEs in India also to examine the major challenges faced by MSMEs for inclusive growth and to find the opportunities available for development of this sector.

\section{LITERATURE REVIEW}

Venkatesh and Muthiah (2012) found that the role of small and medium enterprises (SMEs) in the industrisal sector is growing rapidly and they have become a thrust area for future growth. This research emphasized that development of SME sector is necessary for the economic well-being of the nation. Also they focus on it is essential that the entrepreneurs along with government support take necessary steps for future development. The above literature highlights at the various aspects viz. performance, growth and challenges of MSMEs in Indian economy.

Dr. Meeravali S., K.Ramesh et al. (March 2017) found that though MSME total working enterprises, emp loyment and market value of fixed assets grown at CA GR of $4.39 \%$, $4.75 \%$ and $6.64 \%$ respectively, the contribution from manufacturing and service sector MSME contribution to GDP is $-1.53 \%$ and $1.82 \%$ respectively. Researchers also suggest that government has to adopt integrated policy,

\footnotetext{
${ }^{1}$ The Planning Commission was an institution in the Government of India, which formulated India's Five-Year Plans, among other functions. In his first Independence Day speech in 2014, Prime Minister Narendra Modi announced his intention to dissolve the Planning Commission. It has since been replaced by a new institution named NITI Aayog.
} 
promote skill development to increase productivity and also providing accessible credit through government sponsored agency exclusively to MSME is essential to increase productivity and contribution to economic growth.

Singh et al. (2012) analyzed the performance of SSI in India and focued on policy changes which have opened new opportunities for this sector. This study concluded that SSI sector has made good progress in terms of number of SSI units, production and employment levels. The study recommended the emergence of technology development and strengthening of financial infrastructure to boost SSI and to achieve growth target.

\section{OBJECTIVES:}

The main objective of the paper is to evaluate the overall growth and developments in the MSMEs sectors in India.

The second objective is to find key challenges faced by the MSMEs sector as well as also to study future prospects of MSMEs and Third objective is to examine government initiative to regenerate the MSMEs sector.

\section{RESEARCH METHODOLOGY}

The current research study is based on "Exploratory" in nature. The major emphasis in such study is on the discovery of ideas and insight (Kothari, 1996). The study is based in secondary data covering 18 years i.e. 2001 to 2018 . All financial data are compiled from MSMEs Annual report, Government of India. Different articles and information available in different journals and magazines are also referred for compilation of this paper.

\section{CONCEPTS}

Small Scale Industrial Un it (SSIs): As per the Government of India (2000), the small scale undertakings are those which are engaged in manufacturing, processing or preservation of goods and in which the investment in fixed assets, whether held on ownership terms, or on lease or by hire purchase, does not exceeds Rs. 1 crore.

Micro Small Medium Enterprise (MSME): Micro, small and medium enterprises as per MSMED Act, 2006 are defined based on their investment in plant and machinery (for manufacturing enterprise) and on equipment for enterprises providing or rendering services. The present ceilings on investment for enterprises to be classified as micro, small and medium enterprises are as follows:

\begin{tabular}{|l|l|l|}
\hline Classification & Manufacturing Enterprises & Service Enterprises \\
\hline Micro & Rs. 2.5 million/ Rs. 25 lakh & Rs. 1 million/ Rs. 10 lakh \\
\hline Small & Rs. 50 million/ Rs. 5 crore & Rs. 20 million / Rs. 2 crore \\
\hline Medium & Rs. 100 million / Rs. 10 crore & Rs. 50 million / Rs. 5 crore \\
\hline
\end{tabular}

Source: MSME at a Glance, 2017

MSME at a Glance:

\begin{tabular}{|c|c|c|c|c|c|}
\hline \multirow{2}{*}{$\begin{array}{l}\text { Sr. } \\
\text { No. }\end{array}$} & \multicolumn{4}{|c|}{ 2006-07 } & \multirow[t]{2}{*}{ 2017-18* } \\
\hline & Economic Parameter & Registered & Unregistered & Total & \\
\hline \multirow[t]{3}{*}{1.} & No. of Enterprises (lakh) & $\begin{array}{l}15.53 \\
(5.94 \%)\end{array}$ & $\begin{array}{l}245.48 \\
(94.06 \%)\end{array}$ & $\begin{array}{l}261.01 \\
(100.00 \%)\end{array}$ & 633.88 \\
\hline & i) Manufacturing Enterprises & 10.35 & 64.18 & 74.53 & --------- \\
\hline & ii) Service Enterprises & 5.18 & 181.30 & 186.48 & ---------- \\
\hline \multirow[t]{5}{*}{2.} & Employment(lakh) & 92.04 & $\mathbf{5 0 2 . 5 7}$ & 594.61 & 1109.89 \\
\hline & i) Manufacturing Enterprises & 79.85 & 224.22 & 304.07 & ----------- \\
\hline & ii) Service Enterprises & 12.19 & 278.35 & 290.54 & ---------- \\
\hline & iii) Male & 73.40 & 412.75 & 486.15 & 844.68 \\
\hline & iv) Female & 18.64 & 89.82 & 108.46 & 264.92 \\
\hline \multirow[t]{3}{*}{3.} & $\begin{array}{l}\text { Average Employment per Unit } \\
\text { (number) }\end{array}$ & 5.93 & 2.05 & 2.28 & $\mathbf{1 . 7 5}$ \\
\hline & i) Manufacturing & 7.71 & 3.49 & 4.08 & ----- \\
\hline & ii) Service & 2.35 & 1.54 & 1.56 & ------- \\
\hline 4. & Share in GDP $(\%)$ & & & $35.13 \%$ & $\begin{array}{l}37.54 \\
(2012-13)\end{array}$ \\
\hline 5. & Fixed Investment (Rs. Crore) & & & $5,00,758$ & \\
\hline
\end{tabular}




\begin{tabular}{|c|c|c|c|c|c|}
\hline 6. & $\begin{array}{l}\text { Employment per Rs. } 1 \text { lakh } \\
\text { investment in Fixed Investment }\end{array}$ & & & 0.19 & \\
\hline \multirow[t]{4}{*}{7.} & Source of Finance (No. in Lakh) & $15.5(6 \%)$ & $245.5(94 \%)$ & $261(100 \%)$ & \\
\hline & No Finance/Self Finance & $13.6(88 \%)$ & $\begin{array}{l}228.5 \\
(93 \%)\end{array}$ & $\begin{array}{l}242.1 \\
(93 \%)\end{array}$ & \\
\hline & Institutional Sources & $\begin{array}{l}1.7 \\
(11 \%)\end{array}$ & $\begin{array}{l}11.8 \\
(5 \%)\end{array}$ & $\begin{array}{l}13.5 \\
(5 \%)\end{array}$ & \\
\hline & Non-Institutional Sources & $\begin{array}{l}0.2 \\
(1 \%)\end{array}$ & $\begin{array}{l}5.2 \\
(2 \%)\end{array}$ & $\begin{array}{l}5.4 \\
(2 \%)\end{array}$ & \\
\hline
\end{tabular}

Sources: Quick Result of $4^{\text {th }}$ All India Census of MSMEs, 2006-07

*Annual Report of Ministry of MSME 2017-18

\section{INTRODUCTION TO ENTREPRENEURS MEMORANDUM (PART II):}

As per the provision of the Micro, Small and Medium Development Act (2006), MSMEs file Entrepreneurs Memorandum (Part I) at DICs. After commencement of the project, the entrepreneur concerned files Entrepreneurs Memorandum (Part-II) / [EM-II]. Prior to enactment of the Micro, Small \& Medium Enterprises Development Act, 2006 (MSMED Act, 2006) there was a system of registration by small scale industrial units to the DICs. Now, filing of EM-II is discretionary for micro, small and medium enterprise engaged in both manufacturing and services. However, it is mandatory for medium scale enterprise engaged in manufacture or production of goods pertaining to any industry specified in the First Schedule of the ID\&R Act, 1951.

\section{Distribution of EM-II by Type of Enterprise}

Out of the total EM-II filed, distribution among micro, small and medium segments are as mentioned in the following table

Table.1: Distribution of EM-II filed MSMEs by type of Enterprise

\begin{tabular}{|c|c|c|c|c|}
\hline Year & Micro & Small & Medium & Total \\
\hline $2007-08$ & 153110 & 16730 & 467 & 172703.00 \\
\hline $2008-09$ & 170262 & 18792 & 702 & 193026.00 \\
\hline $2009-10$ & 185180 & 23870 & 1409 & 213206.00 \\
\hline $2010-11$ & 205112 & 29125 & 1263 & 238429.00 \\
\hline $2011-12$ & 242539 & 34225 & 2949 & 282428.00 \\
\hline $2012-13$ & 275867 & 41502 & 5449 & 322818.00 \\
\hline $2013-14$ & 296526 & 59127 & 7338 & 362991.00 \\
\hline $2014-15$ & 346206 & 70933 & 8219 & 425358.00 \\
\hline Average & $\mathbf{2 3 4 3 5 0}$ & $\mathbf{3 6 7 8 8}$ & $\mathbf{3 4 7 5}$ & $\mathbf{2 7 6 3 7 0}$ \\
\hline CAGR $^{\mathbf{2}}$ & $\mathbf{1 0 . 7 4 \%}$ & $\mathbf{1 9 . 7 9 \%}$ & $\mathbf{4 3 . 1 2 \%}$ & $\mathbf{1 1 . 9 3 \%}$ \\
\hline
\end{tabular}

Source: Annual Report, 2016-17(Min istry of MSME, GoI)

The average growths of Micro, Small and Medium enterprises are 234350, 36788 and 3475 respectively with overall average growth rate of $11.93 \%$. The maximum growth was witnessed by medium scale enterprises is $43.12 \%$. At the year ending $2014-$ 15 , there were 234350 micro enterprises with annual growth rate is $10.74 \%$.

2 The compound annual growth rate (CAGR) is the mean annual growth rate of an investment over a specified period of time longer than one year. 


\section{Total no. of EM-II filed pertaining}

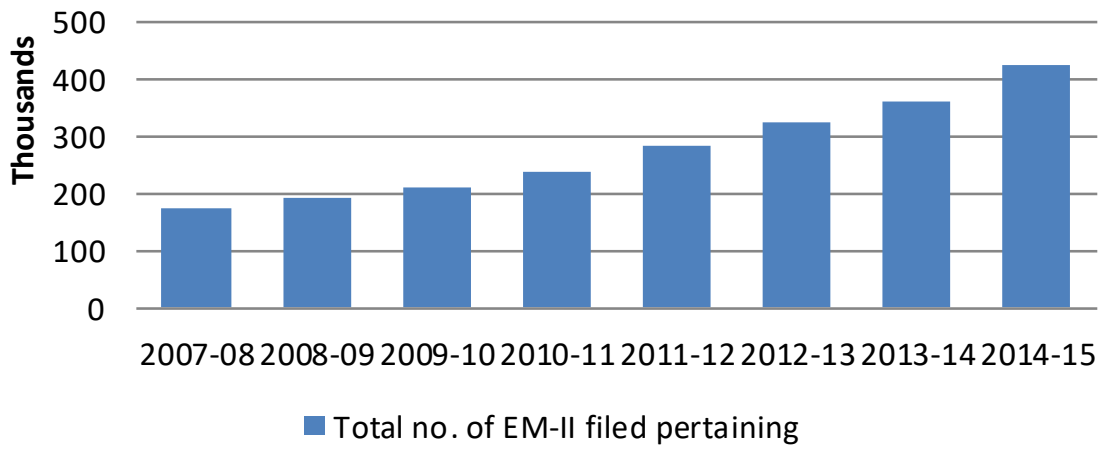

Fig.1: Total Number of EM-II filed

When the Micro, Small and Medium Enterprise Act were introduced in 2006, MSME in India always has shown a progressive and positive growth. If we look in the above graph the total number of Entrepreneur Memorandum - II filed from 2007 to 2015 (Fig 1), it's very clear that it is an upward moving trend.

Table.2: Status of working MSMEs, Employment, Investments and Gross Output in India

\begin{tabular}{|c|c|c|c|c|}
\hline Year & $\begin{array}{c}\text { No. of } \\
\text { working } \\
\text { enterprise }\end{array}$ & $\begin{array}{c}\text { employment } \\
\text { (in Lakh) }\end{array}$ & $\begin{array}{c}\text { market value } \\
\text { of FAs (in } \\
\text { crore) }\end{array}$ & $\begin{array}{c}\text { Gross } \\
\text { output (in } \\
\text { crore) }\end{array}$ \\
\hline $2001-02$ & 105.21 & 249.33 & 154349 & 282270 \\
\hline $2002-03$ & 109.49 & 260.21 & 162317 & 314850 \\
\hline $2003-04$ & 113.95 & 271.42 & 170219 & 364547 \\
\hline $2004-05$ & 118.59 & 282.57 & 178699 & 429796 \\
\hline $2005-06$ & 123.42 & 294.91 & 188113 & 497842 \\
\hline $2006-07$ & 361.76 & 805.23 & 868543.79 & 1351383.45 \\
\hline $2007-08$ & 377.37 & 842.23 & 917437.46 & 1435179.26 \\
\hline $2008-09$ & 393.7 & 881.14 & 971407.49 & 1524234.83 \\
\hline $2009-10$ & 410.82 & 922.19 & 1029331.46 & 1619355.53 \\
\hline $2010-11$ & 428.77 & 965.69 & 1094893.42 & 1721553.42 \\
\hline $2011-12$ & 447.73 & 1012.59 & 1176939.36 & 1834332.05 \\
\hline $2012-13$ & 467.54 & $1,061.40$ & $1,268,763.67$ & $* *$ \\
\hline $2013-14$ & 488.46 & $1,114.29$ & $1,363,700.54$ & $* *$ \\
\hline $2014-15$ & 510.57 & $1,171.32$ & $1,471,912.94$ & $* *$ \\
\hline Average & $\mathbf{3 1 8 . 3 8 4 2 8 5 7}$ & $\mathbf{7 2 3 . 8 9 4 2 8 5 7}$ & $\mathbf{7 8 6 9 0 1 . 9 3 7 9}$ & $\mathbf{1 0 3 4 1 2 2 . 1 4}$ \\
\hline CAGR & $\mathbf{1 1 . 9 4 \%}$ & $\mathbf{1 1 . 6 8 \%}$ & $\mathbf{1 7 . 4 8 \%}$ & $\mathbf{1 4 . 3 0 \%}$ \\
\hline
\end{tabular}

Source: MSME Annual Report 2014-15, GoI

** Data Not Available

Note: From 2001-02 to 2005-06, the data for this period is small scale industries (SSI).

Performance of Micro, Small and Medium (MSME) sector is assessed by conduct of periodic All India Census of the sector. As per the results of Fourth All India Census of MSME, the sector contributes significantly to the number of enterprises, employment and output of the country. Based on the data sets of Fourth All India Census of MSME, augmented with data sets of EC, 2005 and growth rate observed during Fourth (1998) and Fifth (2005) Economic 
Census, the performance of MSME Sector is summarized as below. It may be noted that the Fourth All India Census of MSME, unregistered sector was assessed by conduct of sample survey of the sector.

It is clear from the table No. 2 that number of enterprises, employment, investment in fixed assets and gross out of MSME units in India show an increasing trend over the fourteen years. From FY 2006-07, figures includes activities of wholesale/retail trade, legal, education \& social services, hotel \& restaurants, transports and storage \& warehousing (except cold storage) for which data were extracted Economic Census 2005, Central Statistics Office, MOSPI. Estimated on the basis of per enterprises value obtained from sample survey of unregistered sector for activities wholesale/retail trade, legal, education \& social services, hotel \& restaurants, transports and storage \& warehousing(except cold storage) which were excluded from Fourth All India Census of MSME, unregistered sector. Number of enterprises and employment registered an annual growth rate of $12 \%$ approximately Where as the value of fixed assets growth rate of $17 \%$ approximately. The last 3 years gross output data is not available so growth rate from 2001 to 2012 is $14 \%$ approximately.

Table.3: Comparative growth rate of MSME sector and Industrial Sector

\begin{tabular}{|c|c|c|}
\hline Year & $\begin{array}{l}\text { Growth Rate of } \\
\text { overall Industry } \\
\text { Sector (\%) }\end{array}$ & $\begin{array}{l}\text { Growth rate of } \\
\text { MSME Sector } \\
(\%)\end{array}$ \\
\hline $2000-01$ & 5.00 & 8.00 \\
\hline $2001-02$ & 2.70 & 6.10 \\
\hline $2002-03$ & 5.70 & 8.68 \\
\hline $2003-04$ & 7.00 & 9.64 \\
\hline $2004-05$ & 8.40 & 10.80 \\
\hline $2005-06$ & 8.20 & 12.32 \\
\hline $2006-07$ & 11.60 & 12.60 \\
\hline
\end{tabular}

\begin{tabular}{|c|c|c|}
\hline $2007-08$ & 8.50 & 13.00 \\
\hline $2008-09$ & 12.80 & 10.30 \\
\hline $2009-10$ & 10.40 & 6.70 \\
\hline $2010-11$ & 7.40 & 4.40 \\
\hline $2011-12$ & 7.80 & 4.40 \\
\hline $2012-13$ & 6.85 & 5.60 \\
\hline $2013-14$ & 6.76 & 9.10 \\
\hline $2014-15$ & 6.54 & 8.56 \\
\hline $2015-16$ & 6.60 & 7.62 \\
\hline CAGR & $\mathbf{1 . 8 1 \%}$ & $\mathbf{0 . 4 5 \%}$ \\
\hline
\end{tabular}

Source: Annual Report of Ministry of MSME

In Table 3 shows that the overall growth of industrial sector and the growth of MSMEs sector during sixteen years. This two sectors shoes moderate to high growth rate during early phase of this period. But early period of last six years growth rate of MSMEs was greater than that of the overall industry growth rate. And later on it is decreasing. In 2000-01, the growth rate of MSMEs was 8.00 and it declined to 6.10 next year, then it increasing to reach up to 13.00 of period 2007 08. Later, it decreased and fell to a down of $4.4 \%$ in $2010-11$ then increased up to 9.10 .

MSME Growth rate of employment and enterprise by sector

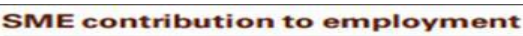

\begin{tabular}{|c|c|c|}
\hline & $\begin{array}{l}\text { Growth rate of } \\
\text { employment }\end{array}$ & $\begin{array}{l}\text { Growth rate } \\
\text { of number of } \\
\text { enterprises }\end{array}$ \\
\hline Manufacturing & $\mathbf{1 8 \%}$ & $\mathbf{2 3 \%}$ \\
\hline
\end{tabular}

Comparison between SMEs contribution to GDP of India and some developed global economies :

SMEs contribution to GDP: India vs. some major global economies Thanks to the dominance of unregistered and unorganised players, India lags far behind its global peers when it comes to GDP contribution from SMEs

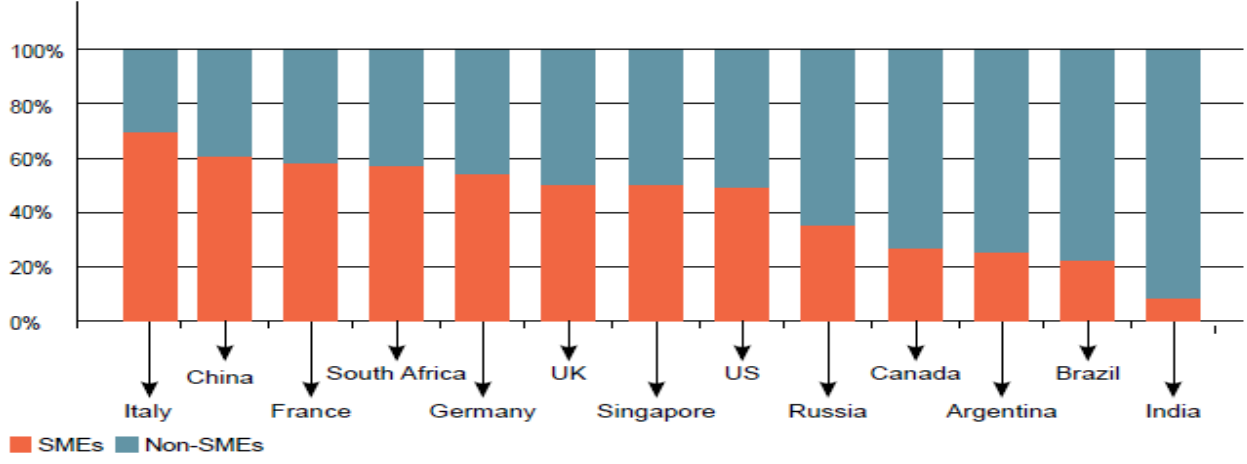


However India MSME compares unfavorably both for employment (21\%) and share of GDP (8\%)

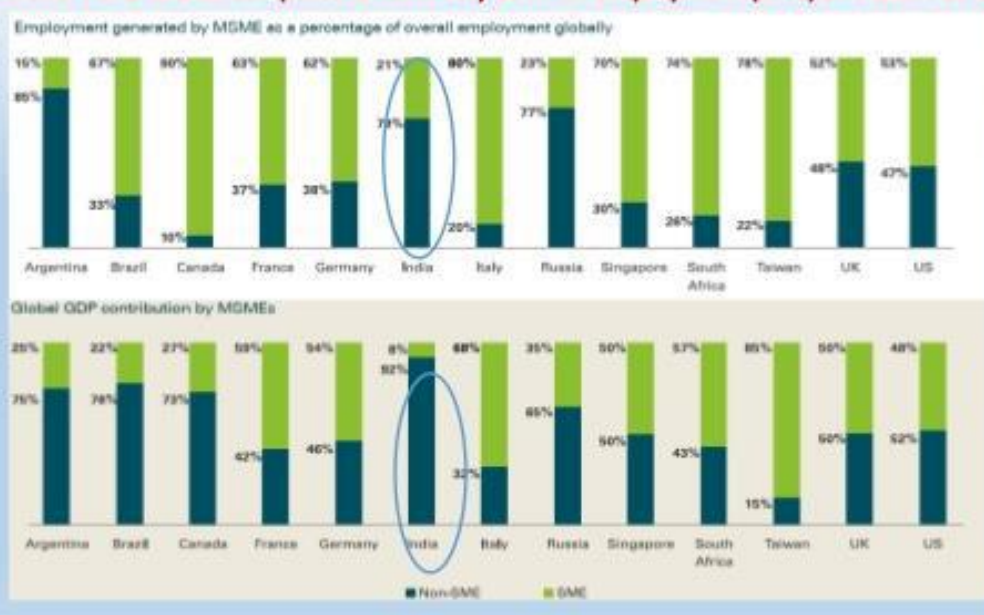

But the expectations is much higher

Significa ntly increasing the share of MSME contribution to GDP from the current 8 per cent to 15 per cent by 2020 Generate employment levels to the extent of $50 \%$ of the overall employment, more than doubling the current MSME workforce of 106 million across agricultural, manuf acturing and services sectors 3 ; and Increasing the share of MSME contribution across key public and private industry sectors fulfilling increasing domestic demand, growth in exports, indigenization and import substitution

Source: Courtry Spesirie MSMt Heports, KrMMG Date si tetimates

Non-MSME Sector Includes - Un-organized / Unregistered enterprises, Large Enterprises including (PSEs, large industrial houses, MNCs)

India needs to create 10 to 15 million job opportunities per annum till 2030 to provide useful employment to its population $^{3}$. In budget 2018-19, the government largely focused on MSMEs as the preferred route for rapid job creation and self-employment. The MSME sectoremploys over 111 million people and contributes nearly $31 \%$ of India's GDP ${ }^{4}$. The total number of enterprises in MSME sector was 46 million with total employment of 106 million. Current MSME employment rate is at $28 \%$ of the overall employment. The current growth of MSME is non-uniform and there exists a significant gap in growth of enterprises across services and manufacturing sectors. Steps to lower this gap must be taken for a balanced growth outlook.

\section{PROBLEMS FACED BY MSMES}

1. Absence of adequate credit from banks- The MSMEs are faced more problem of credit from the banks. The loan process of the banks is very lengthy, so much documentation required with high cost processing fee. The banks are not providing adequate amount of loan to the MSME's.

2. Competition from MNC's- The MSME's is facing the huge competition from the multinational companies. Because of multinational companies are providing quality goods at low price.

3. Poor infrastructure- MSME's are developing so rapidly but there is lack of infrastructure facilities.

\footnotetext{
3 Planning Commission Report (2012) - Creating a Vibrant Entrepreneurial Ecosystem in India - Sunil Mitra

${ }^{4}$ Business Standard, Budget 2018-CRISIL SME TRACKER: Budget 2018's focus on MSMEs to spur job creation
}

Because of poor infrastructure, their production capacity is very low with production cost is very high.

4. Unavailability Resources-Due to non availability of raw materials, work force and other inputs in the market. Therefore it is very difficult to produce the products at affordable prices.

5. Lack of advanced technology- In the MSME's sector, there is a lack of awareness of advanced technologies of production. They are using traditional methods for producing goods.

6. Lack of distribution of marketing channels-MSME's not adopting innovative ideas for promotion of the products distribution and advertisements. Because of ineffective advertisement and poor marketing channels leads to a very poor selling.

\section{FUTURE PROSPECTS OF MSMES}

1. Employ ment generation: There are large opportunities in the field of manufacturing and service rendering of MSME's. In the field of retail and manufacturing sector, MSMEs are generating different and ample amount of employment.

2. Focus on customer satisfaction: Primarily, MSMEs manufacturing goods focus on test and preferences, liking and disliking of the consumer. But now a day they produce goods according to the needs or expectations of the customers. So the MSMEs can be more customer satisfaction oriented.

3. Minimization of regional imbalance: The MSMEs will utilize the manpower of rural areas so such areas of the nation can equally developed through the running of 
MSME units in rural areas. So this is helpful to minimize or remove the regional imbalance.

4. Development of Export: In the international market, there will be a large demand of Indian product like wooden items, other handmade articles etc. So MSMEs have the potential to improve the export of India.

5. Attraction of Foreign Investment: The Indian MSMEs are the growing sectors and their growth rate and return on investment is satisfactory. This sector can attract foreign investment in India, so their growth rate increasing drastically.

\section{CONCLUSION}

Micro, Small and Medium Enterprises contributes to economic development of India in various ways such as employment generation in rural and urban areas, providing goods and services at affordable costs. The current Market value of Indian MSMEs is $\$ 5$ billion. It is estimated that in terms of Market value, the sector accounts for about $45 \%$ of the industrial output, $40 \%$ of total exports of the country, $45 \%$ industrial units, 42 million employment and more than 8000 products in Indian economy. Govern ment of India has taken various in itiatives to make this sector more vibrant and significant player in development of the Indian economy. The definition and coverage of the MSME sector was broadened MSME Development Act 2006 which recognized concept of 'enterprise' to include both manufacturing and service sector besides defining medium enterprises setting up a Board for developing policy frameworks and indicating procurement policy.

\section{REFERENCES}

[1] Sudha Venkatesh, K. Muthiah, 'SMEs in India: Importance and Contribution', Asian Journal of Management Research, Volume 2, issue 2, 2012.

[2] Dr. Meeravali S., K.Ramesh, K. A jay Kumar, G.Sekhar Babu, SSRG International Journal of Economics and Management Studies (SSRG-IJEMS) - volume 4 issue3 March 2017. Online available at https://www.researchgate.net/publication/316582194_ Performance_of_MSMEs_Sector_in_India Singh, R., Verma, O.P., and Anjum, B. (2012), 'Small Scale Industry: An Engine of Growth', Zenith International Journal of Business Economics \& Management Research, Vol.2 Issue 5. Online available at http://www.zenithresearch.org.in

[3] Dey Dr. Sanjeeb Kumar MSMEs IN INDIA: IT'S GROWTH AND PROSPECTS [Journal] // Abhinav National Monthly Refereed Journal of Research in commerce and management. - 2014.
[4] Kothari [Report]. - 1996.

[5] Mayank Aggarwal and Misra Asit Govt changes definition of MSMEs, bases it on annual revenue [Report]. - [s.1.] : Industan Times, 2018. Article available online at

[6] https://www.hindustantimes.com/india-news/govtchanges-definition-of-ms mes-bases-it-on-annualrevenue/story-ko7QpcvlYElqrrk724FmiN.html

[7] Murthy D.Sudarsana Performance Evaluation of MSMEs - An Empirical Study Abstract [Journal] // International Journal of Research and Development A Management Review (IJRDMR). - 2016. - 1: Vol. 5 .

[8] PlanningCommission Sub- Group on Flow of Private Sector Investments for MSME Sector [Report].

[9] MSME at a Glance, Government of India 2017, https://msme.gov.in/sites/default/files/MSME_at_a_G LANCE_EN_0.pdf

[10] http://www.dc ms me.gov.in/publications/EMII-201415.pdf

[11] All India Report of Sixth Economic Census https://msme.gov.in/sites/default/files/All\%20Ind ia\%2 0Report\%20of\%20Sixth\%20Economic\%20Census.pdf

[12] Growth Of Micro, Small And Medium Enterprises (Msmes) In India, Dr.S.Kishore, BIMS International Journal of Social Science Research, file://C:/Users/Priya/Downloads/16227-18165-1SM.pdf

[13] Growth and Develop ment of MSMEs - An Analytical View, M.Sankaraiah, B.Mohan, International Journal of Research and Development - A Management Review (IJRDMR), ISSN (Print): 2319-5479, Volume-5, Issue-4, 2016 http://www.ird india.in/journal_ijrd mr/pdf/vol5_is s $4 / 10$ .pdf

[14] Business Standard - Budget 2018

[15] http://www.businessstandard.com/budget/article/budget-2018-s-focus-onmsmes-to-spur-job-creation-118020500998_1.html 